\title{
Gross and radiographic assessment of foot with claw disorders in culled cattle at Nsukka abattoir
}

Ogbanya, K. C. and Eze, C. A.

Department of Veterinary Surgery,

Faculty of Veterinary Medicine, University of Nigeria, Nsukka

Abstract

Corresponding author: kenneth.ogbanya@unn.edu.ng; 08036027640

Claw disorders are either infectious or non-infectious which have been found to be the cause of more than $90 \%$ of all lameness cases observed in dairy cattle. Against this background, descriptive and cross-sectional study was to determine the common radiographic features of claws with gross disorders using abattoir samples. A total of 40 claws were collected from Nsukka abattoir. The claws were examined for identification of different types of gross lesions. Two radiographic exposures, dorso-plantar and lateral views of each of the claws were taken and evaluated for radiographic changes. White line degeneration (WLD), sole erosion and horn heel erosion were the most prevalent gross lesions with 35\%, 30\% and 20\% prevalent rates respectively. Bulb erosion and claw wall fissure were the least occurred claw disorders with 5\% and 5\% occurrence. Infectious claw disorders (55\%) had a relatively higher occurrence than the non-infectious disorders (45\%). The most prominent radiographic abnormalities were noted in the second (PII) and third phalanxes (PIII) region. The radiographic changes were sinking of PIII (10\%) subluxation of PII (5\%), foreign body penetration (15\%), exostoses (5\%) of the pastern (PII) bone. Laminitis occurred in $30 \%$ of the sampled claws. Concurrent appearance of more than one radiographic feature in a single claw was noted in the claw samples. In conclusion, radiographic examination revealed that typical changes of chronic laminitis were among the most common pathological features recorded.

Keywords: cattle, claw, disorder, foot, laminitis, radiograph

Un Bilan macroscopique et radiographique du pied avec troubles des griffes chez les bovins de réforme à l'abattoir de Nsukka

Ogbanya, K. C. et Eze, C. A.

Department of Veterinary Surgery,

Faculty of Veterinary Medicine, University of Nigeria, Nsukka

Corresponding author: kenneth.ogbanya@unn.edu.ng; 08036027640

\section{Résumé}

$\overline{\text { Les troubles des griffes sont soit infectieux, soit non infectieux, ce qui s'est avéré être la cause }}$ de plus de $90 \%$ de tous les cas de boiterie observés chez les bovins laitiers. Dans ce contexte, une étude descriptive et transversale visait à déterminer les caractéristiques radiographiques communes des griffes présentant des troubles macroscopiques à l'aide d'échantillons d'abattoir. Au total, 40 griffes ont été collectées à l'abattoir de Nsukka. Les griffes ont été examinées pour identifier différents types de lésions macroscopiques. Deux expositions radiographiques, vues dorso-plantaire et latérale de chacune des griffes ont été prises et évaluées pour les changements radiographiques. La dégénérescence de la ligne blanche (le 'WLD'), l'érosion de la sole et l'érosion du talon de la corne étaient les lésions macroscopiques les plus fréquentes avec respectivement 35\%, 30\% et 20\% de taux de prévalence. L'érosion des bulbes et la fissure de la paroi des griffes ont été les moins affectées 
des griffes avec 5\% et 5\% d'occurrence. Les troubles infectieux des griffes (55\%) avaient une fréquence relativement plus élevée que les troubles non infectieux (45\%). Les anomalies radiographiques les plus importantes ont été notées dans la région de la deuxième (le 'PII') et de la troisième phalange (le 'PIII'). Les changements radiographiques étaient la descente de la subluxation 'PIII' (10\%) du 'PII' (5\%), la pénétration de corps étrangers (15\%), les exostoses (5\%) du paturon (le 'PII'). Une laminite est survenue dans 30\% des griffes échantillonnées. L'apparition simultanée de plus d'une caractéristique radiographique dans une seule griffe a été notée dans les échantillons de griffe. En conclusion, l'examen radiographique a révélé que les changements typiques de la fourbure chronique faisaient partie des caractéristiques pathologiques les plus courantes enregistrées.

\section{Mots clés : bovins, griffe, trouble, pied, fourbure, radiographie}

\section{Introduction}

Claw disorders are either infectious or noninfectious (Greenough, 2007). Claw disorders in dairy animals cause a great deal of economic loss in terms of milk production and reproduction losses (Booth et al., 2004; Garbarino et al., 2004; Singh et al., 2011). Claw disorders have been found to be the cause of more than $90 \%$ of all lameness cases observed in dairy cattle (Murray, et al., 1996). Lameness in animals has emerged as the most severe problem in recent years, at organized farms. It is considered to be the third most expensive health problem of dairy animals after mastitis and infertility (Esslemont, 1990), having adverse effect on their welfare. Lameness is considered to be a major welfare and economic problem both in beef and dairy farming. Economically, lameness due to lose in milk yield, weight and fertility and increases the risk of culling (Hogeveen et al., 2011; Reyher et al., 2011). Because of the low level of farmer's knowledge, training and awareness, the risk of claw disease not being discovered until the clinical condition becomes very obvious. The chances of restoring the productivity of the animal, its milk yield or weight gain, depend largely on rapid medical or surgical treatment, the course of which relates directly to accurate diagnosis and appropriate treatment (Hogeveen et al.,
2011). Radiography as a diagnostic tool is often necessary and in most cases, useful to reach to a diagnosis (Ahmed and Shekidef, 2012). The objectives of the study were to macroscopically and radiographically examine claw disorders of the culled cattle at Nsukka Abattoir.

\section{Materials and methods}

The Ikpa Nsukka market abattoir and the slaughter slab was purposively selected because the abattoir maintains a regular slaughter of cow. Post-mortem hindlimb digits with gross claw disorders were amputated and collected for assessment. The choice of hindlimbs was based on the fact that hindlimbs have been reported to be responsible for a higher percentage of foot lameness in cattle (Hernandez et al. 2002). A total of 20 cow-feet of the hindlimbs (40 claws) with claw-related lesions were macroscopically and radiographically examined.

\section{Macroscopic examination of the claw}

The claws were thoroughly washed, assessed for macroscopic lesions identification. The weight-bearing surface of the claws were examined for any gross claw lesions. Excessively overgrown claws were trimmed using hoof knife to effectively reduce their sizes. The horn of the sole was trimmed with a hoof knife to expose any underlying claw lesions and any 


\section{Ogbanya and Eze}

observable claw lesions recorded accordingly. The claw lesions were photographed using a digital camera (Sony DSC-S80, 4.1Mega Pixels). Radiographic assessment of the claws disorder was using standard radiographic techniques (Beige and Bakir, 2005).

\section{Radiographic examination of the claw}

The collected feet were transported to the Radiology Unit of the Department of the Veterinary Surgery and Radiology, UNN for radiographic examination. Lateromedial and dorsoplantar views were obtained using exposure factors of $20 \mathrm{mAs}$, $80-88 \mathrm{kV}$ and FFD of $70 \mathrm{~cm}$. The obtained radiographs were interpreted properly.

\section{Data management and analysis}

Presence or absence of a particular lesion were recorded as "1" (meaning "Yes" for presence of a claw lesion), and "0" (meaning "No" for absence of a claw lesion). Percentage distribution of the lesions were computed as: Proportion of the number of positive observations of each lesion type divided by the total number of feet sampled, multiplied by 100 to express it as a percentage.

\section{Results}

A total of 20 cows were enrolled at the end of the study period and had complete data observations.

Photographic representation of the various gross lesions such as white line degeneration (WLD), sole corium erosion (SCE), horn heel erosion (HHE) and bulb erosion (BE) is shown in Plate 1. Pictorial representation of digital dermatitis (DD) and claw wall fissure (CWF) are shown in Plates 2 and 3 respectively.

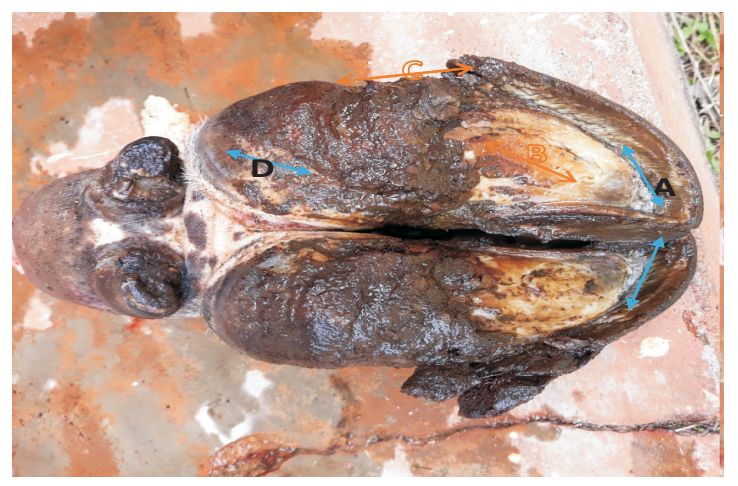

Plate 1: A photograph showing white line degeneration (A), sole corium erosion (B), horn heel erosion (C) and bulb erosion (D).

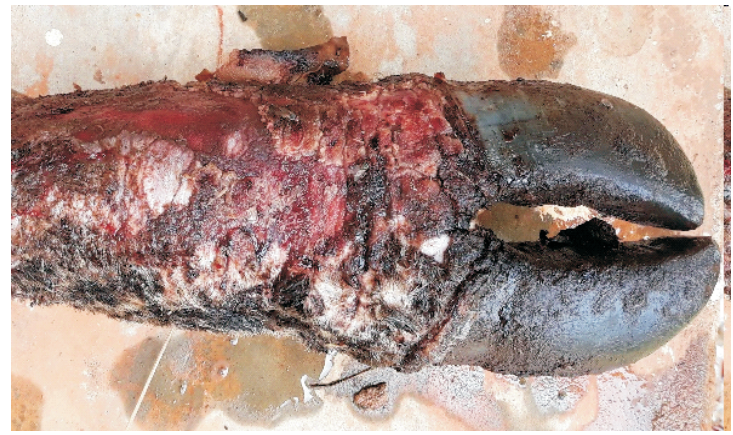

Plate 2: Photograph of the digit showing digital dermatitis 


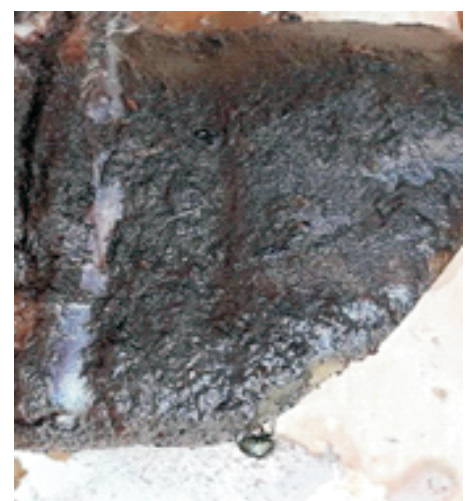

Plate 3: Photograph showing claw fissure.

Table 1: Prevalent rate of different claw disorders in 20 abattoir feet (40 claws) samples.

\begin{tabular}{lll}
\hline Claw Disorders & $\begin{array}{l}\text { No of } \\
\text { Occurrence }\end{array}$ & $\begin{array}{l}\text { Percentage of } \\
\text { Occurrence }\end{array}$ \\
\hline White line degeneration (WLD) & 7 & $35 \%$ \\
Sole erosion (SE) & 6 & $30 \%$ \\
Horn Heel Erosion(HHE) & 4 & $20 \%$ \\
Claw wall fissure (CWF) & 1 & $5 \%$ \\
Digital dermatitis (DD) & 2 & $10 \%$ \\
Bulb erosion (BE) & 1 & $5 \%$ \\
Total & $\mathbf{2 0}$ & $\mathbf{1 0 0}$ \\
\hline
\end{tabular}

Table 2: Prevalent rate of infectious and non-infectious claw lesions

\begin{tabular}{lll}
\hline Type of claw infection & Number of occurrence & Percentage of Occurrence \\
\hline Infectious & 11 & $55 \%$ \\
Non-infectious & 9 & $45 \%$ \\
Total & $\mathbf{2 0}$ & $\mathbf{1 0 0}$ \\
\hline
\end{tabular}

\section{Radiographic changes}

The most prominent radiographic abnormalities were noted in the second phalanx (PII) region of the culled cows. The radiographic changes observed were partial subluxation of the distal end of PII (Plate 4), foreign body penetration and sinking of pedal bone (Plate 5), exostosis on the distal shaft of the PII (Plate 6). The prevalent rate of each of the various radiographically identified claw lesions is presented in Table 1 while the prevalence of infectious and non-infection claw lesions is presented in Table 3. Based on the clinical and radiographic examination 6 cows were affected with laminitis (Table 4).

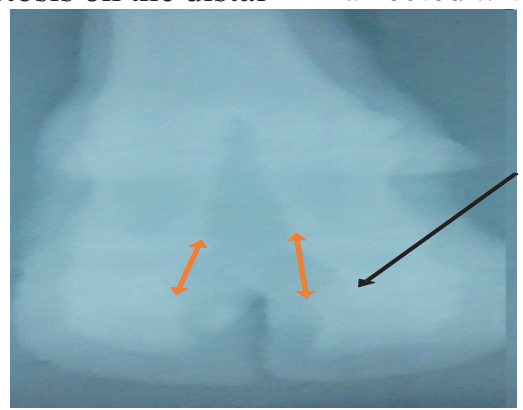

Plate 4: Radiograph of the digit showing subluxation of the distal end of PII (black arrow). 
Ogbanya and Eze

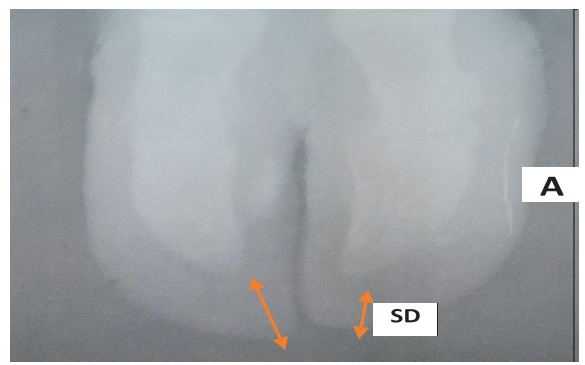

Plate 5: Radiograph showing metal object that penetrates through the claw horn (A) and a shorter sole depth (SD) which is typical of "sinking" pedal bone.

Plate 6: Radiograph showing mild exostosis (arrow) on the distal end of PII.

\section{Discussion}

Claw lesions such as heel erosion, white line separation and sole erosion have been incriminated as major underlying predisposing cause for development of laminitis with resultant lameness in cattle (Beige and Bakir, 2005; Nocek, 1997). The high prevalence rate of white line degeneration $(35 \%)$, sole erosion $(30 \%)$ and heel horn erosion (20\%) observed in this current study almost proportionally compares with the $30 \%$ prevalence rate of laminitis seen among the examined cows. This observation supports works of other researchers who have previously employed presence of, heel erosion, white line separation and sole ulcer for the diagnosis of laminitis in cattle (Beige and Bakir, 2005; Bergsten, 1994; Greenough and Vermunt, 1991). In this study, all the cows with sole corium erosion and horn heel erosion were radiographically confirmed to be laminitis affected cows. This linkage is likely to be attributed to the fact that the 
initial phase of the pathogenesis of laminitis involves changes in pododermal microvasculature, which results in vascular tissue damage and subsequently manifest as ulcer in the sole (Nocek, 1997; Hirschberg and Plendl, 2005). Sole ulcer is probably the main sign that can be used to diagnose subclinical phase of claw lesions particularly laminitis. The results of this study indicated that cows with laminitis have more than one associated claw lesion and deformity. This report is consistent with the previous findings which stated that laminitis is a predisposing cause of lesions such as sole ulcers, white line separation, heel erosion and double soles (Nocek, 1997; Beige and Bakir, 2005). White line separation was mostly found on the lateral claw of the hind limbs. White line separation has been reported previously to be attributed to the fact that white line is the weakest point of impact which is likely to succumb and fissure under pressure insults (Baggott and Russell, 1981). High prevalence rate of infections of the claw observed in this study might be attributed to poor environmental hygiene in the cattle environment. The presence of infectious digital dermatitis (10\%) which is also known as digital papillomatosis or "hairy warts" in cows suggested a managemental factor in its aetiological predisposition. Unhygienic environment would promote development and spreading of this contagious lesion (Weaver, 1993). Results of this study indicate that laminitis in cows can tentatively be predicted by presence of some claw deformities. This predictive association between claw deformities and laminitis is supported by findings of others (Greenough, 1987; Ebeid, 1993; Weaver, 1993). Claws affected with infectious digital dermatitis had narrowed medial pedal bone. This finding is related to the findings of Nguhiu-Mwangi et al. (2007) who reported narrowing of pedal bones in extremely deformed chronic laminitic claws of dairy cows. However, narrowing of the pedal bones could be due to an osseous dissolution resulting from osseous necrosis (osteosis). One of the causes of osteosis is associated with nutrition and oxygen especially when there is compromise of local blood supply (Jubb et al., 1993). Exostosis of the pastern bone was also observed in the claws affected with digital dermatitis. Similarly, Maclean (1970), reported exostosis of the pedal bone in claws with chronic laminitis. The cause of exostosis could be attributed to periostitis (inflammation) of the pedal bane following prolonged inflammatory stimuli in chronic laminitis. The outgrowths or projections (exostosis) seen on the pastern bone (PII) could be a result of laminitis (Jubb et al., 1993). The cause of PIII (pedal bone) sinking in this study could be attributed to damage of the laminar tissue attaching the pedal bone to the dorsal aspect of the claw. Rotation of phalanges usually leads to joint angulation.

\section{Conclusion}

The study showed that most of the radiographically examined claws revealed the typical changes of chronic laminitis and were among the most common pathological features recorded.

\section{References}

Ahmed, I. H and Shekidef, M. H. 2012. Incidence and management of bovine claw affections and their economic impact: A field study on dairy farms. Journal of American Science, 8(6): 46-61.

Baggott, D. G and Russell, A. M. 1981. Lameness in cattle. British Veterinary Journal 137: 113-132.

Belge, A. and Bakir, B. 2005. Subclinical laminitis in dairy cattle: 205 selected cases. Turkish. Journal of Veterinary Science, 29: 9-15.

Bergsten, C. 1994. Haemorrhages of the 
sole horn of dairy cows as a retrospective indicator of laminitis. an epidemiological study. Acta Journal of Veterinary Sccotd. 35. 55-66.Booth, C. J, Warnick, L. D., Grohn, Y. T., Maizon, D. O., Guard, C. L. and Janssen, D. 2004. Effect of lameness on culling of dairy cows. Journal of Dairy Science, 87(12): 4115-4122.

Ebeid, M. 1993. Bovine laminitis: a review. Veterinary. Bulletin 63: 205-213.

Esslemont, R. J. 1990. The costs of lameness in dairy herds. In: R. D. Murray (Ed), Proceedings of $\mathrm{Vl}^{\text {th }}$ International Symposium on Diseases of the Ruminant Digit, British Cattle Veterinary Association, Liverpool, pp 237251.

Garbarino, E. J., Hernandez, J. A., Shearer, J. K., Risco, C.A. and Thatcher, W. W. 2004. Effects of lameness on ovarian activity in postpartum Holstein cows. Journal of Dairy Science, 87: 4123-4131.

Greenough, P. R. 2005. Heel erosion, sole erosion (bruising), double soles, sole foreign bodies and horizontal ridges of the dorsal wall, www.cowdoc.net.

Greenough, P. R. and Vermunt, J. J. 1991. Evaluation of subclinical laminitis in a dairy herd and observations on associated nutritional and management factors. Veterinary Record, 128:1117.Greenough, P. 2007. Infectious diseases and other conditions affecting the interdigital space. In: Greenough P., editor. Bovine Laminitis and Lameness. 1st ed. WB Saunders/ Elsevier, Philadelphia, PA.p199-220.

Hernandez, J., Shearer, J. K. and Webb, D. W. 2002. Effect of lameness on milk yield in dairy cows. Journal of
American Veterinary Medical Association, 220: 640-644.

Hirschberg, R. M. and Plendl, J. 2005. Pododermal angiogenesis and angioadaptation in the bovine claw. Microscopy Research Techniques, 66 : 145 155 Hogeveen, H., Huijps, K. and Lam, T. J. 2011. Economic aspects of mastitis: New developments. New Zealand Veterinary Journal, 59: 16-23.

Jubb, K. V. F., Kennedy, P. C. and Palmer, N. 1993. In: Pathology of Domestic Animals, 3nJ Ed, Vol. 1. Academic Press, New York, Inc. Harcourt Brace Jovanovich Publishers, pp 61-63.Maclean, C. W. 1970. A post-mortem X-ray study of laminitis in barley beef animals. Veterinary Record, 86: 457-462.

Murray, R. D., Downham, D. Y., Clarkson, M. J., Faull, W. B., Hughes, J. W., Manson, F. J, Merrit, J. B., Russel, W. B., Sutherst, J. E. and Ward, W. R. 1996. Epidemiology of lameness in dairy cattle, description and analysis of foot lesions. Veterinary Record, 138: 586-591.

Nguhiu-Mwangi, J., Mbithi, P. M. F., Wabacha, J. K. and Mbuthia, P. G. 2007. Radiographic features of laminitic claws of dairy cows around Nairobi. A Journal of the Kenya Veterinary Association: The Kenya Veterinarian 31(2): $72-78$.

Nocek, J. E. 1997. Bovine acidosis, implications on laminitis. Journal of Dairy Science 80: 1005-1028

Reyher, K. K., Dufour, S., Barkema, H. W., Des Coteaus, L., DeVries, T. J., Dohoo, I. R., Keefe, G. P., Roy, J. P and Scholl, D. T. 2011. The national cohort of dairy farms - A data collection platform for 
Gross and radiographic assessment of foot with claw disorders in culled cattle at Nsukka abattoir

mastitis research in Canada. Journal of Dairy Science, 94: 16161626.

Singh, Y., Lathwal, S. S., Chakrabarty, A. K., Gupta, A.K., Mohanty, T. K., Raja, T. V., Dangi, R. L. and Roy, B. K. 2011. Effect of lameness (hoof disorders) on productivity of Karan Fries crossbred cows. Animal Science Journal 82: 169-74.
Weaver, A. D. 1993. Aseptic laminitis of cattle. Interdigital and Digital dermatitis, indicator of laminitis. an epidemiological study. Acta Veterinaria Scandinavica, 35: 5566.

Received: $18^{\text {th }}$ August, 2020 Accepted: $21^{\text {st }}$ November, 2020 